Trinity University

Digital Commons@ Trinity

English Faculty Research

English Department

$1-2016$

\title{
Saul Bellow as a Novelist of Ideas: Introduction to the Forum
}

Victoria Aarons

TrinityUniversity, vaarons@trinity.edu

Gustavo Sánchez-Canales

Follow this and additional works at: https://digitalcommons.trinity.edu/eng_faculty

Part of the English Language and Literature Commons

\section{Repository Citation}

Aarons, V., \& Sánchez-Canales, G. (2016). Saul Bellow as a novelist of ideas: Introduction to the forum. Partial Answers: Journal of Literature and the History of Ideas, 14(1), 57-62. doi: 10.1353/pan.2016.0004

This Article is brought to you for free and open access by the English Department at Digital Commons @ Trinity. It has been accepted for inclusion in English Faculty Research by an authorized administrator of Digital Commons @ Trinity. For more information, please contact jcostanz@trinity.edu. 


\title{
Saul Bellow as a Novelist of Ideas: Introduction to the Forum
}

\author{
Victoria Aarons \\ Trinity University, San Antonio, TX \\ Gustavo Sánchez-Canales \\ Universidad Autónoma de Madrid
}

On the occasion of his acceptance of the Nobel Prize for Literature, Saul Bellow asked, "What is at the center now?" (2015a: 299). This question gets at the heart of a lifetime of literary attempts to find "the center," to expose the core of what it means to be human in the volatile, unstable, and explosive twentieth century. In defense of what, for Bellow, was the singular preoccupation of his lengthy and distinguished literary career, he insists that "[o]ut of the struggle at the center has come an immense, painful longing for a broader, more flexible, fuller, more coherent, more comprehensive account of what we human beings are, who we are, and what this life is for" (299). For Bellow, one of the responsibilities of the novelist, if not the central, fundamental aim, is to expose "the center," and to adjudicate among the many explanations, rationalizations, defenses, and subterfuges that constitute modern life. As Bellow's introspective and skeptical interlocutor, Artur Sammler, sees it, the self-invented "[i]ntellectual man" of the twentieth century has become "an explaining creature . . . in one ear and out the other" (1978: 3). Yet the impulse to explain must somehow find its aesthetic temper, its voice, within but also separate from the cultural cacophony. According to Bellow, "a novel of ideas ... becomes art when the views most opposite to the author's own are allowed to exist in full strength. ... [T]he opposites must be free to range themselves against each other and they must be passionately expressed on both sides" (2015b: 130). For Sammler, as for Bellow, the value in human existence, in navigating both the tangled "theater of the soul" and the cacophony - the plentitudes and platitudes - of the great experiment of twentieth-century America, is in "[e]liminating the superfluous. Identifying the necessary" $(234,278)$.

Bellow remains one of the most decorated and internationally acclaimed American novelists of the twentieth century, the recipient of the Nobel Prize for Literature (1976), the Pulitzer Prize (1975), thrice re- 
cipient of the National Book Award (1954, 1965, 1971), as well as of other notable national and international awards, including the Prix International de Littérature (1965), the Croix de Chevalier des Arts et Lettres (1968), the National Medal of Arts (1988), the PEN/Malamud Award (1989), and the Gold Medal for Fiction from the American Academy and Institute of Arts and Letters (1977). Bellow wrote novels of contemplation and of meditated reflection - thinking people's novels. For Bellow, the measure of a novelist's worth lies in the courage of truth-telling, of extracting and baring "the center," the essence of experience, for the novel, as Bellow puts it, "is balanced between a few true impressions and the multitude of false ones that make up most of what we call life. It tells us that for every human being there is a diversity of existences, that the single existence is itself an illusion in part, that these many existences signify something, tend to something, fulfill something; it promises us meaning, harmony and even justice" (2015a: 300). The novel, for Bellow, becomes an occasion for reflection - for both writer and reader - a solitary enterprise in which that which is "fundamental, enduring, essential" might be isolated and considered in light of our accountabilities and reckoning (300).

For it is in the quietude of the moment that the "assignment," as Sammler puts it, might be made clear, "[a]ssigned to figure out certain things, to condense . . . some essence of experience" (1978: 274). Bellow cautions against the "noise" of modern life that distracts one from the essential, from the center, from the essence of human experience. The antagonist, for Bellow, is "noise." He puts the problem squarely in the prologue to the recently published collection of nonfiction, There Is Simply Too Much to Think About: "The enemy is noise. By noise I mean not simply the noise of technology, the noise of money or advertising and promotion, the noise of the media, the noise of miseducation, but the terrible excitement and distraction generated by the crises of modern life.... [T] he noise of life is the great threat" (2015b: 7).

For a writer so deeply suspicious of words, of language's propensity to dissemble, to stupefy, to prevaricate, and to defraud, Bellow remains a writer of ideas, of disputation, of soliloquy, of thoughtful, meditative introspection. It is, paradoxically, through the continuous libretto of language, the tumult of words, that the din of the confusions and clamor of the mayhem of modern existence is momentarily arrested. As Nathaniel Rich suggests, "This divide between 'the Great Noise' and 'the quiet zone' of contemplation, without which serious, sustained thought is im- 
possible, was more than a motif for Bellow; it was the main artistic crisis of twentieth-century America" (14). Indeed, of the "violent uproar" of our times, Bellow argues in the Nobel address, "We are still able to think, to discriminate, and to feel. The purer, subtler, higher activities have not succumbed to fury or to nonsense. . . [I]t is possible to cut through the noise and reach the quiet zone. ... When complications increase, the desire for essentials increases too" (296). One reads Bellow "for the exuberant prose, the rigorous wrestling with ideas, and the exquisitely vivid evocation of the eras and places that he occupied. In a noisy world, his fiction creates a refuge - a quiet zone" (Rich 14).To be sure, it is in the shape of Bellow's words - a seemingly endless colloquy of reflective, life-affirming words - that order is created from disorder by the novelist's voice of conscience, "motivated by a desire for truth" (15). The novelist's project is, for Bellow, a moral endeavor: "The writer in any case finds that he bears the burdens of priest or teacher. Sometimes he looks like the most grotesque of priests, the most eccentric of teachers, but I believe the moral function cannot be divorced from art" (Bellow 2015b: 164).

Amidst the chaos of modern life, Bellow's fiction is a stay against confusion. His writing sets the record straight, uncluttering the pandemonium, getting at the essential. In prose that is, in itself, an argument against totalitarianism and didacticism, Bellow's fiction, in keeping with his high standards for the novelist, serves "to create scale, to order experience, to give value, to make perspective and to carry us toward sources of life, toward life-giving things" (2015b: 125). "Individualism," says Sammler, "is of no interest whatever if it does not extend truth" (1978: 234). So we read Bellow, in large part, in order to read ourselves and the lives we messily inhabit, "this life we think we can understand" (1978: 237). Perhaps the final measure of Bellow's achievement might be summed up in his own measure of ironic and candid self-reflection: "The record will show what the twentieth century has made of me and what I have made of the twentieth century" (2015b: 373).

The essays that follow suggest the ways in which Bellow's perspicacious gaze has been cast upon the twentieth century and how his fiction shows the exacting finesse of grappling with big ideas. The Forum begins with two differing approaches to The Victim (1947), an early novel that raises such questions as anti-Semitism, moral accountability, the nature of suffering, and opportunities for reprieve and redemption. In "Faces in a Sea of Suffering: The Human Predicament in Saul Bellow's The Victim," Victoria Aarons examines the suggestions of the two epigraphs that 
open the novel, one from "The Tale of the Trader and the Jinni," in The Thousand and One Nights, and the other from Thomas de Quincey's The Pains of Opium. Both, Aarons argues, are cautionary tales of accountability and moral reckoning that follow Bellow's anxious protagonist as he uncomfortably confronts, in the figure of his double, his failed responsibilities to others. In "Schooling in grief': A Comparative Analysis of the Theme of Suffering in Saul Bellow's The Victim and Chaim Potok's The Chosen," James W. Flath takes up the premise of suffering, a refrain that runs throughout Bellow's fiction, and, drawing upon the paradigmatic figure of the sufferer in The Book of Job, ultimately rewarded by God for his endurance and faith, compares the affirmative direction of Bellow's and Potok's perspectives. Flath argues that both writers show the possibility of redemption through suffering, which, as Bellow puts it in Herzog, is a "schooling in grief."

The forum then moves to Bellow's recurring, at times indirect, preoccupation with the Holocaust. Aimee Pozorski's "Bonfire in summer camp': Defamiliarization and the Holocaust," juxtaposes Bellow's 1970 novel Mr. Sammler's Planet with Philip Roth's 2010 novel Nemesis. In comparing these two major post-war American-Jewish voices, Pozorski demonstrates how both approach the complexities of Holocaust representation. In showing their differing styles of Holocaust representation - Bellow's literal descriptions of the atrocity and Roth's allegorical account - Pozorski proposes a shift in Holocaust representation from the 1970 s to the twenty-first century, including the topos of the defamiliarized summer camp. While, for Bellow, the question is what it means to survive death, Roth reframes the question as what its mean to survive the camp only to face one's own guilt.

Emilio Cañadas-Rodríguez's article “'An Alice in Wonderland Proposition,' or, Childhood in Saul Bellow's 'By the Saint Lawrence' and 'Zetland: By a Character Witness"' demonstrates the condensation of the narrative of ideas in the short fiction in terms of Bellow's statement that "smaller versions of life are perhaps more truthful." The article examines the position of childhood in Bellow's short stories where the protagonists engage in an uneasy return to the past, exploring the influence of childhood on their identity and personhood.

Moving to two of Bellow's major novels, Willis Salomon's essay "Saul Bellow on the Soul" considers the conceptual depth and reach of the idea of personhood in Bellow's characters. The novels Humboldt's Gift and Ravelstein, Salomon suggests, testify to Bellow's career-long 
preoccupation with the idea of "soul" as a function of both individual character and as the "character" of culture: the hero-figures of the two works, novels spanning almost three decades, reveal, through the affective largeness that Bellow gives them, a type of intellectual heroism, the loss of which Bellow believes has severe, even catastrophic, cultural consequences.

In " Recover the world that is buried under the debris of false description': The Influence of Romantic Poetry on Saul Bellow's Dean's December," Gustavo Sánchez-Canales addresses a major concern that runs throughout Bellow's career: the defense of individuality. Sánchez-Canales continues the discussion of Humboldt's Gift, demonstrating Bellow's concern with the pernicious effects that modern civilization exerts on the individual, extending this discussion to Bellow's 1982 novel The Dean's December. The essay shows how, for Bellow, the reconstruction of the inner self is accomplished through the imaginative mind or, under the influence of Romantic poetry, through one's "poetic genius"; the essay explores this claim, against the backdrop of selected poems of William Blake, P. B. Shelley, and W. B. Yeats, showing the ways in which the Bellovian heroes such as Augie March, Eugene Henderson, and Moses Herzog seek the natural world as a way of embracing a kind of balanced sensibility.

The Forum concludes with Judie Newman's discussion of the 2014 New Perspectives Theatre Company's stage adaptation of Bellow's wellknown short story "Him with His Foot in His Mouth." Newman shows the influence of the different endings of the story and the theatrical productions on our understanding of the story's comic effects, contrasting comedy as the expression of an aggressive, materialistic society (as theorized in Freud's The Joke in Relation to the Unconscious) with "green" comedy as a means of reforming society (with reference to Northrop Frye's The Anatomy of Criticism). In doing so, Newman demonstrates the life of Bellow's fiction beyond the page.

Thus, in honor of the centennial of Bellow's birth and the $10^{\text {th }}$ anniversary of his death, this Forum pays tribute to this deeply erudite and perspicacious novelist of ideas, whose influence extends well beyond his time and whose fiction continues to capture the attention of scholars in the United States and abroad. 


\section{Works Cited}

Bellow, Saul. 1978 [1970]. Mr. Sammler's Planet. New York: Penguin. . 2015a [1976]. "The Nobel Lecture." Saul Bellow: There Is Simply Too Much to Think About: Collected Nonfiction. Ed. Benjamin Taylor. New York: Viking, pp. 291-300.

- 2015b. "Prologue: Starting Out in Chicago," "Where Do We Go From Here? The Future of Fiction," "The Writer as Moralist," and "A Jewish Writer in America: A Lecture." Saul Bellow: There Is Simply Too Much to Think About: Collected Nonfiction. Ed. Benjamin Taylor. New York: Viking, pp. 1-7, 121-30, 155-65, and 356-73.

Rich, Nathaniel. 2015. "Bellow: The 'Defiant, Irascible Mind." The New York Review of Books 62/10 (June 4): 10-16. 